\title{
Agnieszka Veres-Guśpiel
}

JAGIELLONIAN UNIVERSITY

AGNIESZKA.VERES-GUSPIEL@UJ.EDU.PL

HTTPS://ORCID.ORG/OOOO-0002-0032-7359

\section{Social Contexts of Indirect Requests in Polish and Hungarian}

\begin{abstract}
The paper presents the influence of social context on illocutionary metonymy in directives evoked by various elements of request scenarios. As the human language activity reflects the physical and social worlds of the intersubjective context (cf. Verschueren 1999), the recognized and construed social relations have an impact not only on addressive forms, but also on the appearance of other elements such as indirectness and its scalarity.

Indirect directives are based on illocutionary metonymic scenarios (Panther and Thornburg 1998) and by evoking a part of the scenario referring to the core action they give access to the illocutionary scenario domain. The scalar nature of indirectness (Panther and Thornburg 1998, see also Panther and Thornburg 1999, 2007 and Thornburg and Panther 1997), depends on the number of evoked elements and their conceptual distance from the core of the request. It can be based on conventional grammatical structures (e.g. auxiliary verbs) or giving hints by only introducing the action scenario. As VeresGuśpiel (2013) has shown the chosen type of indirectness is influenced by social context and the weight of a directive (for the latter, see also Csató and Pléh 1988, Pléh 2012).

The main question of the presented research regards types of illocutionary metonymy, that can be experienced in various social contexts and what their frequency of use is.
\end{abstract}

Keywords: social contexts, indirectness, illocutionary metonymy, illocutionary scenarios 


\section{Introduction}

The paper, based on Polish and Hungarian data, presents the influence of social context on illocutionary metonymy in directives evoked by various elements of scenarios. The adopted perspective takes into account the socio-cultural situatedness of language activity (Croft 2009), since grammatical constructions and operations are representations of domain-general cognitive abilities (Tátrai 2013, 199) and knowledge of our social world.

As a human language activity is understood in, and as a social interaction, the recognized and construed social relations have an impact on the usage of addressive forms, oftentimes understood as main markers of linguistic politeness. Nevertheless, as the presented research shows, social context has an impact on the appearance of indirectness and its scalarity. The indirectness in directives is based on illocutionary metonymic scenarios (Panther and Thornburg 1998). By referring to the part - but not to the core - of the scenario, the access to the scenario domain is gained, and the indirect request can be contextualized in the frames of the referred scenario (for more on the role of domains in metonymy, see Croft 1993).

Depending on the part of the scenario being evoked, directives may be based on the BEFORE, CORE, or AFTER metonymy. In the gathered material indirect request, both in Polish and Hungarian, the substantial part of indirect requests is based on BEFORE metonymy. When being direct the data providers referred to the CORE of the scenario.

The scalarity of indirectness (Panther and Thornburg 1998, 1999, 2007, Thornburg and Panther 1997), is governed by the accessibility to the scenario domain - the more accessible it is, the request is perceived as more clear and evident, leaving a small possibility of other interpretations of the speaker's intentions. The accessibility of domain depends on the number of the evoked elements and the conceptual distance of the element from the core. As the presented research shows, referring to the most distant parts of the domain could be observed in distant social relations, and when the request was perceived as a big and difficult one.

The paper, by presenting the types of illocutionary metonymy appearing in various social contexts, shows that the understood and construed social context correlates not only with used addressive forms and the use of a grammatical person but also on the other elements of the request such as its indirectness, showing also - depending on the social context - patterns in the use of various types of indirectness (for the interaction of metonymy and grammar see: Brdar and Brdar Szabó 2017, 126-149).

As human language activity, a social interaction, the recognized and construed social relations have an impact on the usage of addressive forms, oftentimes understood as main markers of linguistic politeness. Nevertheless, as the presented research shows social context has an impact on appearance of indirectness and its scalarity. 


\section{Research method and preliminary remarks}

The research is based on data elicited from Polish and Hungarian informants (aged 19 to 35 , total number of L1 data providers: 87) in their L1 by a discourse completion test. The test contained 9 different situations, with socio-culturally diverse situations, adding up to a total of 28 situations. The collected data (2436 answers in total) was analyzed regarding the types, number, frequency and social context of instances of illocutionary metonymy in directives.

The informants were aged 19 to $35.90 .7 \%$ of Hungarian women had finished secondary education. Among Polish data providers, $77.3 \%$ had secondary education. 9.3\% of Hungarians and $22.7 \%$ of Polish informants had completed higher education.

Table 1. Number and education level of participants

\begin{tabular}{lcccc}
\hline \multicolumn{1}{c}{ L1 } & \multicolumn{2}{c}{ POLISH } \\
\hline GENDER & SECONDARY & HIGHER & SECONDARY & HIGHER \\
\hline EDUCATION LEVEL & 23 & 3 & 11 & 7 \\
\hline NUMBER OF PARTICIPANTS & 52.3 & 6.8 & 25 & 15.9 \\
\hline PERCENTAGE & \multicolumn{5}{c}{ HUNGARIAN } \\
\hline L1 & \multicolumn{2}{c}{ WOMEN } & MEN \\
\hline GENDER & SECONDARY & HIGHER & SECONDARY & HIGHER \\
\hline EDUCATION LEVEL & 30 & 2 & 9 & 2 \\
\hline NUMBER OF PARTICIPANTS & 69.8 & 4.65 & 20.9 & 4.65 \\
\hline PERCENTAGE & \multicolumn{7}{c}{ HEN }
\end{tabular}

The social relations differed in terms of hierarchy (boss, teacher), acquaintanceship (stranger, acquaintance, friend) and family bonds (sibling, mother, mother-in-law, grandmother). The analyzed directives also differed in terms of the type of request (asking for information, favor or something of value).

The answers were classified for the types of directive (asking for information, an object, or making an effort), since the research by Pléh and Csató (1988) showed that the type of request had an impact on the appearance of indirectness. Indirect requests do not express the intention of the speaker in an obvious way but rather through metonymic structures which refer to the intended action, relying on elements from the script associated with the request. Characteristically for metonymy, one of the elements activates (in varying degrees of strength) the script of the action, depending on how far conceptually it is in a conceptual frame (see: Panther and Thornburg 2011, 256). Conventionally, indirect requests are also based on metonymic relations; in Hungarian, they involve the tud ('can') auxiliary verb and conditional mood. When making requests, the speaker should take into account the character of his or her social relation with the addressee and the type of request. Depending on the type, fulfilling it demands various amounts of energy, time or money. In the case of an information request, the amount of invested energy is relatively small; this type requires verbal ac- 
tion and the sharing of information from the speech partner. In the research presented here, the sharing of information - on the whereabouts of a fitting room and a street - did not have any strategic value. In the case of asking for value, the addressee had to give or lend something and in the case of asking for a favor, he or she had to make a time and energy investment.

The request is perceived as bigger if the investment of time or effort in fulfilling it is considered to be big, or smaller if the investment of time or energy needed to fulfill the request is smaller. While considering the weight of the request, the speaker takes into account his/her socio-cultural knowledge about what one can ask in the given type of relation and whether this kind of request is conventional.

Before presenting detailed results, a few general remarks are in order. According to the research data, the number of non-conventionally indirect directives increased with social distance and the weight of the request. Being direct was restricted only to close social relations (e.g. friend, sibling, mother).

Conventional indirect directives appeared in typical social relations and social situations, non-conventional indirectness and hinting appeared in the case of non-typical requests, in both close and distant social relations, or requests perceived as face-threatening.

Finally, hinting was based on evoking the very first elements of the scenario or on condition of fulfilling it and often relied on shared contextual knowledge.

\section{Indirectness as metonymic structure}

Indirectness in our language activity has a crucial role in expressing the metonymic nature of our thinking. Metonymy (similarly to metaphor) is one of the basic conceptual and linguistic figures of thought and language (Panther and Thornburg 2017, 275; and Panther and Thornburg 2011, 239; Panther and Radden 1999; Barcelona 2000), which is present not only in language activity but also in interpreting meanings in general (Panther and Thornburg 2007).

In the processes of metonymy, one entity in a conceptual domain is reached through another entity (Langacker 1993, 30; see also: Kövecses 2005, 149; and Kövecses and Radden 1998, 21). Metonymic structures build relations within conceptual domains so that the target content can be reached through another element, the source content. The relation's strength is subject to variation, with the distance between the two elements determining to what extent the source element is salient (Panther and Thornburg 2011, 242).

Panther and Thornburg discuss not only predicative, propositional, or referential metonymy (Panther and Thornburg 2011, 246-247). In a series of other papers (Panther and Thornburg $1998 ; 1999 ; 2003 ; 2006 ; 2007 ; 2009)$ they state that metonymy appears also at the speech act level, which they call illocutionary metonymy. An indirect speech act presents one of the parts of the scenario for a given speech act, and depending on which part is presented, the BEFORE, CORE, or AFTER type indirect speech act is adopted. 
Depending on which part of the scenario is being represented, that before the requested action (BEFORE), that after the action (AFTER) or a part of the action itself (CORE), a BEFORE, CORE or AFTER indirectness appears. When asking about ability (e.g. Can you pass the salt, please?), an indirect metonymic structure is presented in such a way that the BEFORE part of the scenario is highlighted, where we assume an ability to execute an action.

If the speech act contains more elements of a given scenario, the target is more easily identified, and it is easier to understand the intention of the speaker. That is why indirectness should be considered as a scalar phenomenon, as it varies in extent, it has a scalar nature (Panther and Thornburg 1998, 768). It is plausible to assume that the extent to which supportive strategies are involved in evoking elements of an action scenario will have an impact on how the indirectness of the utterance is perceived.

This is because meaning, including discursive meaning, is presented through frames (Fillmore [1982] 2006), ICMs (Lakoff 1987), and scenarios (Panther and Thornburg 1998, 756). The scenarios are built up from elements that are in metonymic relation with the entire scenario, and the elements that create a connection between the whole scenario and the evoked elements build up the context of the utterance. Also, it is important to mention that during socialization, through experience, we learn different scenarios, and thus the interpretation of indirect acts is connected with identifying a proper scenario by the speaker and the addressee. These scenarios contain sets of actions combined with typical (language-specific) language activity. For example, in Polish a conventional way of asking what time it is, is to ask if one has a watch (Masz zegarek?).

As Panther and Thornburg argue in several papers, the scalarity of indirectness is also governed by the place of the element in the illocutionary scenario, a model of which is presented below:

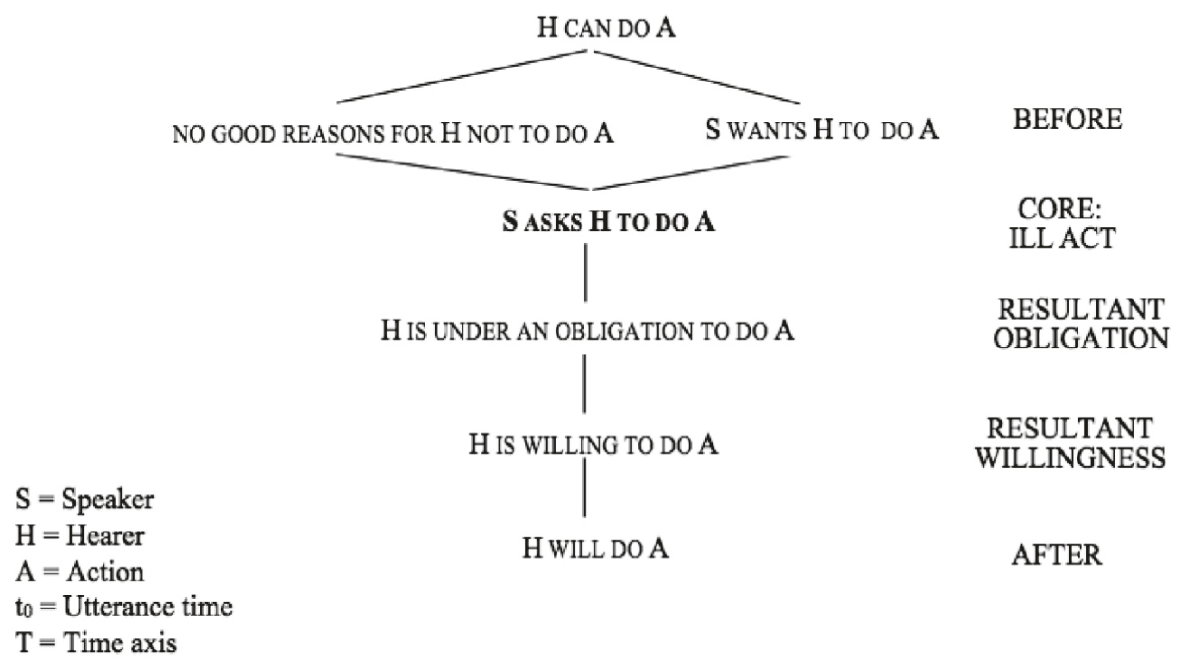

Figure 2. Illocutionary frame of the request (Panther and Thornburg 2017, 282) 
The scalarity in their model depends on whether the evoked element is closer or more distant to the CORE of the scenario, and the closer it is to the core, the more easily it is accessed, in this way reducing the extent of indirectness.

The metonymic structures appearing in utterances evoke a part of the scenario, namely the part preceding the action (BEFORE type indirectness), the consequences of the action (AFTER), or the action itself (CORE). This is why the metonymic structure of asking about ability (Could you pass the salt?) highlights the fact that in the scenario of fulfillment there should be an ability to do the requested action in the first place.

In the results presented below, the main strategies concentrated on the presence of the needed item (Nincs egy fölösleges jegyed? Eng. Do you have a spare ticket?), asking about ability (using auxiliary verbs both in Polish and in Hungarian), mentioning that there is no good reason not to give/pass the item, or no good reason not to carry out the requested action, so indirectness was based on the conditions of fulfilling the scenario, in other words, the BEFORE type indirectness played a dominant role.

The CORE type directives are realized as direct ones, with the speaker asking the addressee to do something for him/her (Switch off the radio!) without using metonymic structures. The research shows that this strategy was used in the case of small social distance, mainly among friends. The CORE type strategy is based on expressing obligation (must, should, mustn't, shouldn't), and it did not appear in the collected material (answers provided by Hungarians and Polish data providers). Predicative metonymy, based on the expression of obligation (must), ability (can, could) or permission (to be allowed) is productive in English or German but its application in Hungarian is much more limited (Panther and Thornburg 2017, 281).

In Hungarian answers, the AFTER type metonymy did not appear at all. Panther and Thornburg (Panther and Thornburg 2017, 282-283) mention only one strategy in this type, in which the addressee is going to give the requested item to the speaker (realized by will, won't, would, wouldn't auxiliary).

It should be mentioned, however, that understanding indirect directives containing metonymic structures requires not only accessing the domain of the illocutionary scenario but also that the speaker and the addressee, relying on shared socio-cultural and contextual knowledge, should access the same scenarios, so they can identify each others' intentions (for more on identifying intentions, see Tomasello 2016, 33-54, Gazzaniga [2008] 2011) which are crucial in identifying the type of speech act (Tátrai 2017) and accessing the right scenario.

The role of contextual knowledge can be clearly seen in the following illustrative example. When there are students in the classroom and a teacher asks one of them if he has enough space, the question can be understood as a direct question about how much space he has. Nevertheless, if we know that students are taking a test and one of them is fidgeting and turning around, the teacher's question about space is treated as an indirect remark that he is trying to cheat on the test. This scenario can be easily and quickly identified not only by the student mentioned but also by his classmates. 
Being indirect is not only the representation of our metonymic way of thinking but it should also be considered as a politeness strategy. When using an indirect speech act, the speaker can still be understood while also giving the addressee more space. In particular, the latter can react in such a way as if he or she had understood the utterance differently (in some cases directly) and in this way the addressee with his or her reaction can override the intended meaning, which can save him or her from saying "no".

The outcome of the research shows that the appearance of indirect directives correlates with the social context - the number of indirect directives increased when social distance between speech partners increased, and when fulfilling the request demanded more (energy or value) investment. The aim of the paper is to describe the correlation between social contexts for directives and the appearance of indirectness, considering it as one of the linguistic markers of how the participants of an interaction understand social context. Politeness here is not understood in the way presented in Brown and Levinson's (1987) work, but rather as being adequate in a given social context (Watts 2003, Locher and Watts 2005). The received answers show that metonymic structures appear in specific patterns depending on the social context of the directive.

The same request is differently formulated in different social contexts and social context has an influence on the type of indirectness, so its appearance should also correlate with the use of $\mathrm{T} / \mathrm{V}$ (where $\mathrm{T}$ stands for second singular forms of verbs, $\mathrm{V}$ for third singular forms of verbs and associated addressive forms, for more on this distinction see Wardhaugh [1995] 2005, 233-256) address forms. As Veres-Guśpiel (2017) shows there is a correlation between social distance, the use of T/V forms, and the appearance of indirectness (Veres-Guśpiel 2017, 75-78). Their occurrence depends on social context, as shown below with percentage data. The figures show the occurrence and type of indirect directives used when informants asked for a bus ticket (Figure no. 3 and 4) and when they were supposed to ask the listener to stop smoking (Figure no. 5 and 6).

\section{Asking for a ticket}

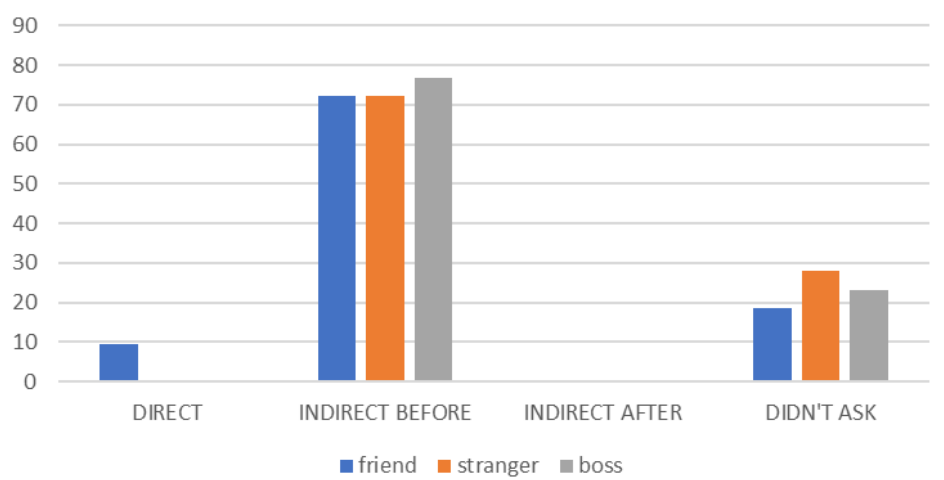

Figure 3. Asking for a ticket (\%) 
Pobrane z czasopisma New Horizons in English Studies http://newhorizons.umcs.pl Data: 26/04/2023 13:03:01

Supportive strategies when asking for a ticket

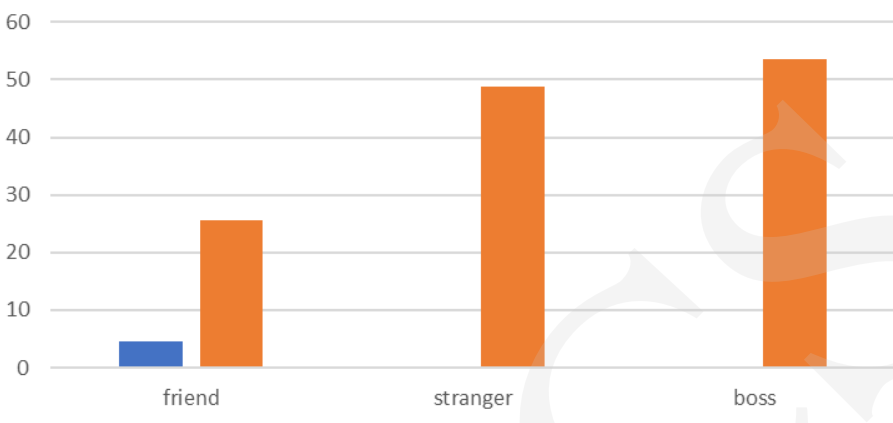

@ SUPPORTIVE STRATEGIES direct request $n$ SUPPORTIVE STRATEGIES indirect request

Figure 4. Supportive strategies when asking for a ticket (\%)

Asking for stopping smoking

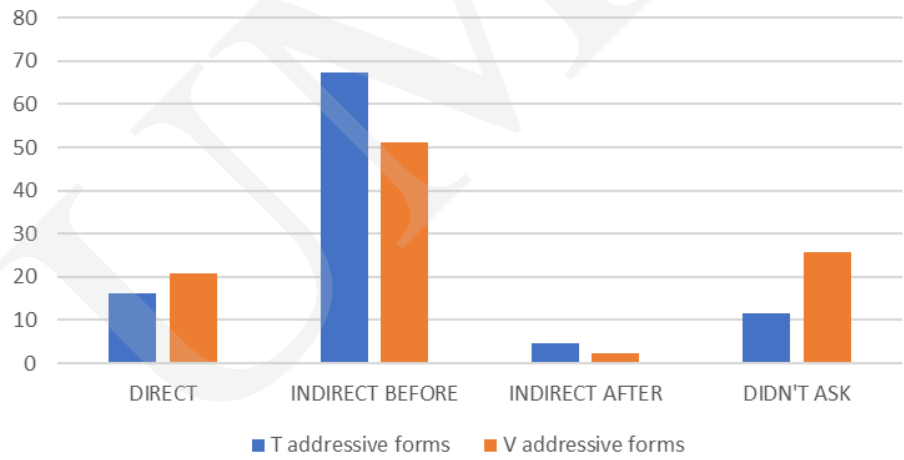

Figure 5. Asking the addressee to stop smoking (\%)

Supportive strategies when askig for stopping smoking

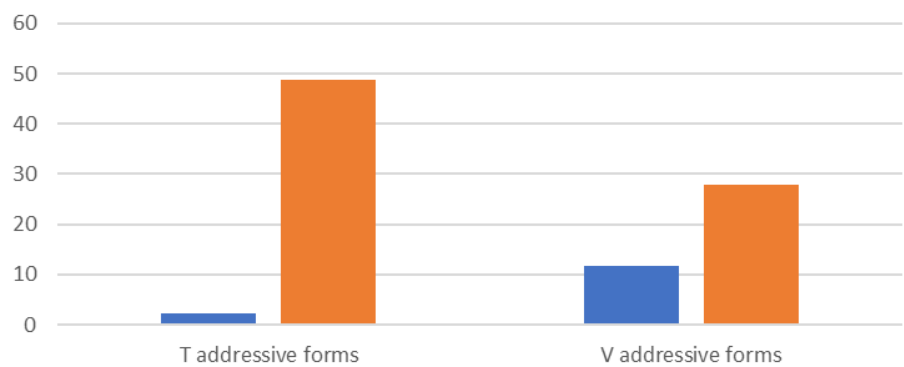

- SUPPORTIVE STRATEGIES direct request $n$ SUPPORTIVE STRATEGIES indirect request

Figure 6. Supportive strategies when asking for stopping smoking (\%) 
A further remark that should be made at this point is that, as the previous research has shown (Blum-Kulka and Olshtain 1984), the structure of a given speech act is language-specific, and so the type of illocutionary indirectness and also its appearance may vary cross-linguistically.

\section{Research results}

\subsection{Directness in Hungarian and Polish}

Before presenting the appearance of indirect directives in Hungarian and Polish answers, it is worth taking a look at what social context directness appears in.

In the Hungarian material, direct requests did not have a high share but rather only appeared in specific situations. In the case of asking for an item, they appeared when speakers were requesting it from a relative (mother: $35 \%$, sibling: $44.3 \%$ ), grandmother: $25.6 \%$, but only $6.8 \%$ in the case of a mother-in-law. What is more, the numbers presented above show that the number of direct requests decreased as the social distance increased.

When asking for a favor, the direct requests appear when asking a friend to change the music in the car $(39 \%)$, when asking friends to stop smoking in a compartment $(41 \%)$ and when asking a friend to check a translation (16\%).

This shows that direct requests appear with small social distance (friend), and close family relations (sibling, mother).

In the Polish answers, direct requests appeared when one should request an item from a relative (mother: $61.4 \%$, sibling: $47.7 \%$, grandmother: $40.4 \%$, but in the case of mother-in-law, only $6.8 \%$ ), i.e. in close familial relations. The figures presented above show that the number of direct requests decreased as the social distance increased - this similarity between answers provided by Hungarians and Polish data providers shows that when choosing if to be direct or indirect the social distance plays a crucial role.

When asking for a favor, the direct requests appear when asking a friend to change the music in the car $(38.6 \%)$, when asking friends to stop smoking in a compartment (61.4\%) and when asking a friend to check a translation (29.5\%). Additionally, in Polish answers, direct requests also appear when the speaker is asking a friend for a loan (20.4\%) or a bus ticket $(22.7 \%)$.

Again, this shows that direct requests appear in scenarios of small social distance (friend) and close family relations (sibling, mother).

\subsection{Social context and types of indirectness}

In the gathered material, indirect requests played a dominant role, and in the case of the Hungarian and the Polish, the BEFORE type of request was typical. In the presented work, I do not analyze the prevalence of the supportive strategies. However, it can be 
observed that in various social contexts the supportive strategies appear in different percentages, indicating certain tendency patterns.

\subsubsection{Asking for an item, value}

In two situations, the data providers were to ask for a small loan (from a friend and a teacher acquaintance), for a bus ticket at a bus stop (from a friend, a stranger and a boss), and for a key to the apartment (from their mother, sibling, grandmother and mother-in-law).

When asking for the item (bus ticket, key), the most frequent strategy was an indirect request. In Hungarian, the most conventional device involves the $t u d$ 'can' auxiliary verb and a conditional suffix, expressing uncertainty as to whether one's partner will be willing to fulfill the request.

When asking for a ticket at a bus stop, the informants asked if the addressee had a spare ticket (stranger: $27.3 \%$, boss: $36.4 \%$, friend: $43.2 \%$ ). When they asked for a key to the apartment, in close family relations (mother, sibling), direct requests appeared (mother: $43.2 \%$, sibling: $34 \%$ ), and when the distance grew, attention was directed onto the speaker with the expression elkérhetem ('May I ask'), that is, by its form drawing attention to the first person. This expression exploits also -hat/-het morpheme used when asking for permission, and is used normally by a person in asymmetrical social relations (younger to older, children to parents, student to teacher etc.)

The tud ('can') verb plus conditional appeared most frequently in situations when complying with the request that could be regarded as difficult, namely when asking for a loan (friend: $45.5 \%$, acquaintance: $41 \%$ ), or when the social distance was regarded as fairly large (mother-in-law, asking for a key: $34 \%$ ).

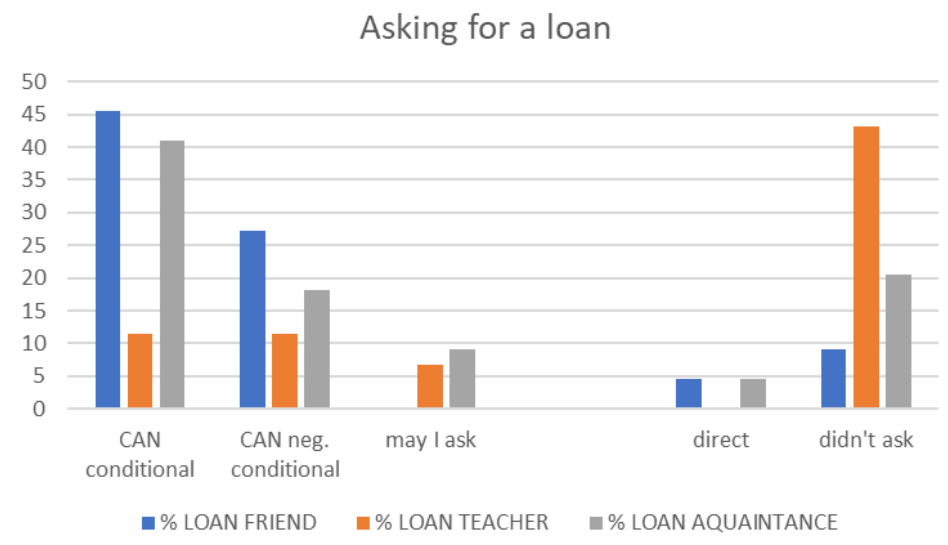

Figure 6. Asking for a loan - the most popular strategies (\%) (Hungarian) 
Pobrane z czasopisma New Horizons in English Studies http://newhorizons.umcs.pl Data: 26/04/2023 13:03:01

Asking for a bus ticket

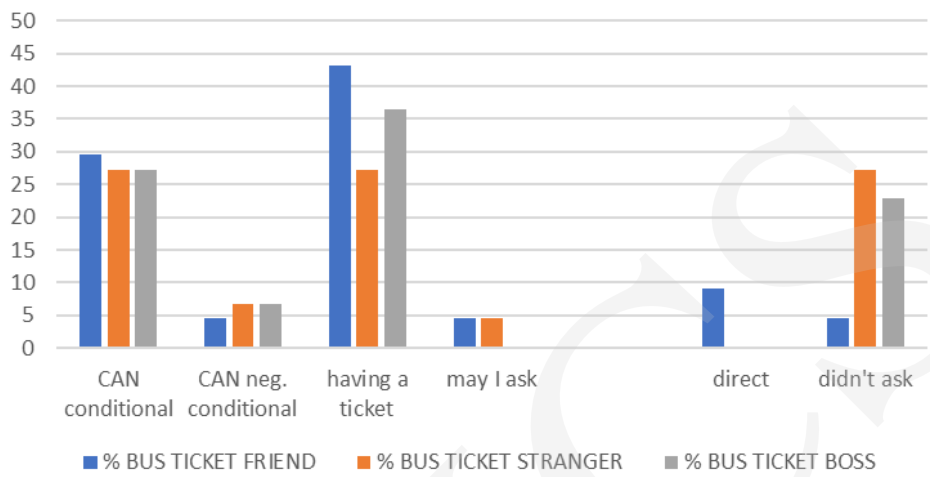

Figure 7. Asking for a bus ticket - the most popular strategies (\%) (Hungarian)

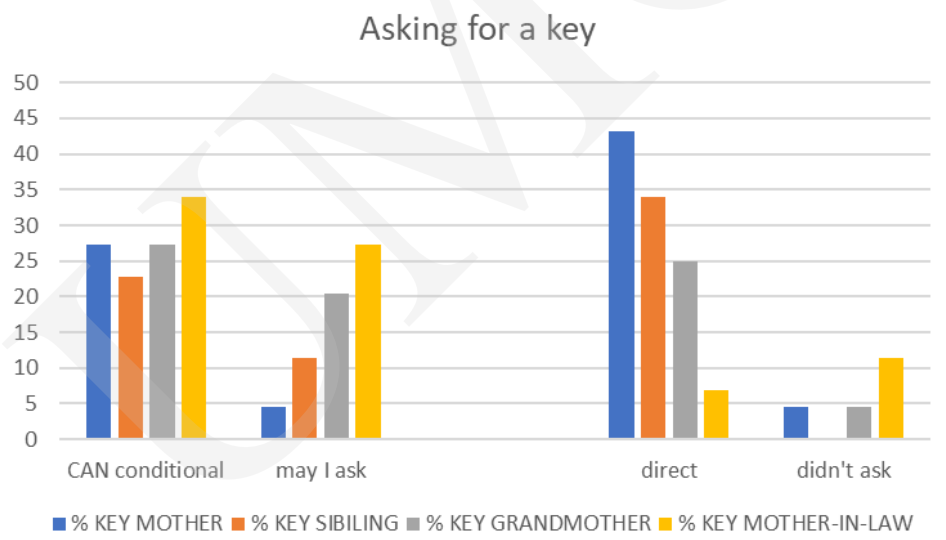

Figure 8. Asking for a key - the most popular strategies (\%) (Hungarian)

Asking for a loan

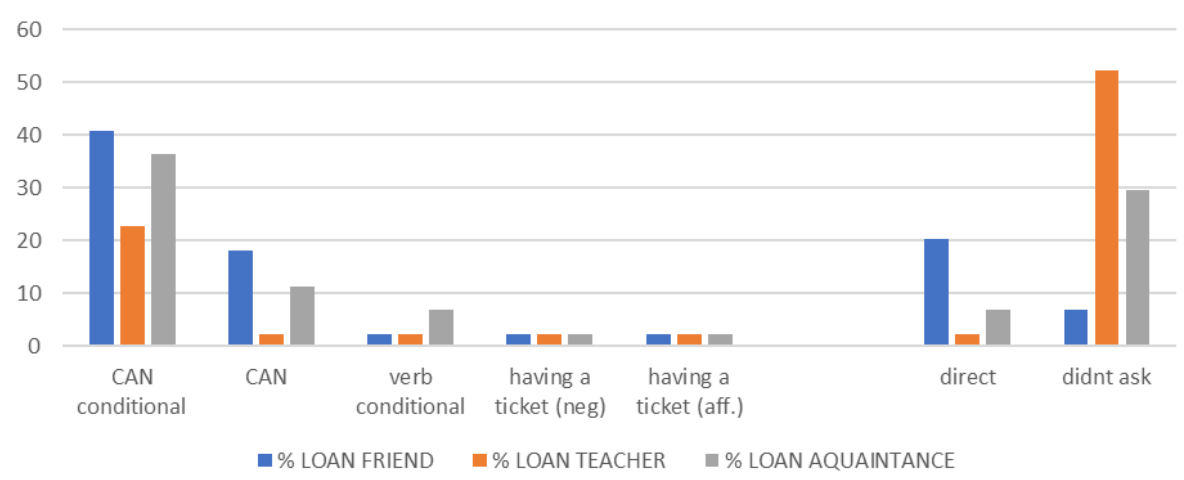

Figure 9. Asking for a loan - the most popular strategies (\%) (Polish) 
Pobrane z czasopisma New Horizons in English Studies http://newhorizons.umcs.pl Data: 26/04/2023 13:03:01

Social Contexts of Indirect Requests in Polish and Hungarian

Asking for a bus ticket

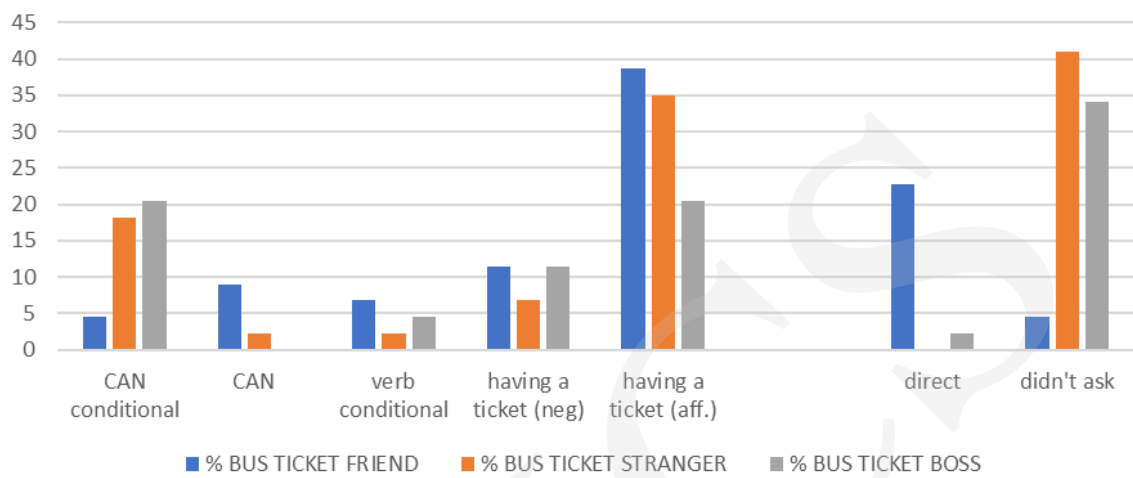

Figure 10. Asking for a bus ticket - the most popular strategies (\%) (Polish)

Asking for a key

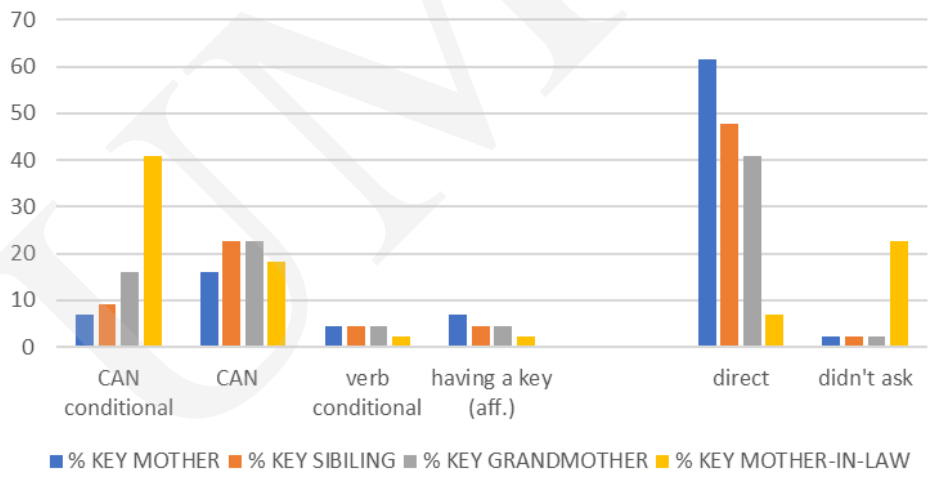

Figure 11. Asking for a key - the most popular strategies (\%) (Polish)

In the Polish answers data providers direct requests appeared the most frequently when asking a friend for a loan (20.4\%). By contrast, their share was much smaller when asking an acquaintance $(6.8 \%)$, and in the case of addressing a teacher, only one informant decided to do it directly $(2.3 \%)$. A bus ticket was considered as an item of smaller value, and direct requests appear in the case of turning to a friend $(22.7 \%)$ and when asking a boss $(2.3 \%)$. The highest number of direct requests appears in close family relations (mother: 61.4\%, sibling: 47.7\% and grandmother: 40.9\%). Polish requests are often expressed with imperative forms. That is why the percentage of direct directives tend to be larger compared to Hungarian directives characterized by the use of conditional forms.

In the scenario of asking for a ticket, when asking a friend, 35\% asked about the condition of fulfilling the request, i.e. if the addressee had a spare one $(38.6 \%$ in affirmative form, $11.4 \%$ in negative form, which gives a total of 50\%). Different degrees of uncertainty were conveyed by the conditional form of the verbs meaning 'can, could' ( $9 \%$ declarative, $4.5 \%$ conditional). Also, in the case of asking a stranger for 
a ticket, this was the most popular strategy (42.8\%). The other popular one was the use of verbs meaning 'can' in a conditional form (18.18\%), expressing a higher degree of doubtfulness than the corresponding declarative form (2.3\%). When turning to one's boss, asking if he/she had a ticket was the most popular choice (32\%), and the second one was to use the verb meaning 'can' in a conditional form (20.45\%).

When asking for something of higher value (a loan), direct requests appear in significant numbers only in interactions with friends (20.4\%). The second and third most popular strategies were to use the verb meaning 'can' in a conditional (friend: $40.9 \%$, acquaintance: $36.4 \%$ teacher: $22.7 \%$ ) or declarative form (friend: $18.2 \%$, acquaintance: $11.36 \%$ teacher: $2.3 \%$ ). This clearly shows that the social context has an influence also on the expression of uncertainty regarding the possibility or the partner's willingness to fulfill the request.

In the scenario of asking for a key from family members, the number of direct requests proves to be the highest. The second strategy was to use a verb meaning 'can' in a declarative form (sibling: $22.7 \%$, grandmother: $22.7 \%$, mother: $15.9 \%$, motherin-law: $18.2 \%$ ). The conditional form of such verbs appears most frequently in the case of increased social distance (mother-in-law: $40.9 \%$, grandmother: $15.9 \%$, mother: 6.81\%, sibling: $9 \%$ ).

To summarize, direct requests typically appeared in the case of small social distance, a high amount of shared background knowledge, and close family relations. Social relations had an impact on expressing uncertainty regarding fulfilling the request, at the same time expressing various expectations if the request could/should be fulfilled. In the case of typically smaller social distance, the expression of uncertainty decreased, and in the event of larger distance, it grew.

\subsubsection{FTA (Face-Threatening Act) type of request}

In the first of two requests considered next, data providers were to ask their friend, acquaintance, boss and teacher to change the music or switch off the radio in a car, which is connected with expressing displeasure and questioning another person's taste, which, by violating one's self-esteem, choice or taste can be considered as FTAs face- threatening acts (Brown and Levinson 1987). In the second situation, the participants were to ask a friend, stranger, boss, and teacher to stop smoking in a non-smoking area, and in this situation, they had to point to the fact that the other person is violating the rules. 
Pobrane z czasopisma New Horizons in English Studies http://newhorizons.umcs.pl Data: 26/04/2023 13:03:01

Social Contexts of Indirect Requests in Polish and Hungarian

\section{Asking to change the music}

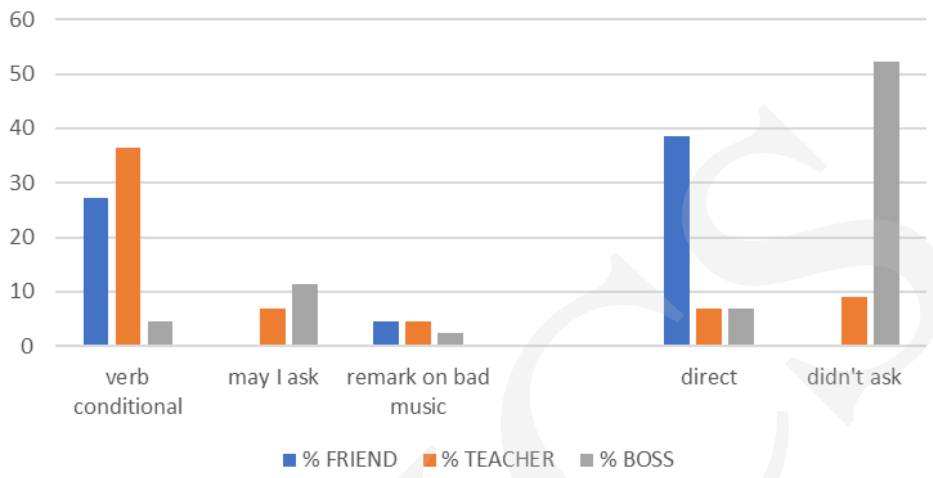

Figure 12. Asking to change the music - the most popular strategies (\%) (Hungarian)

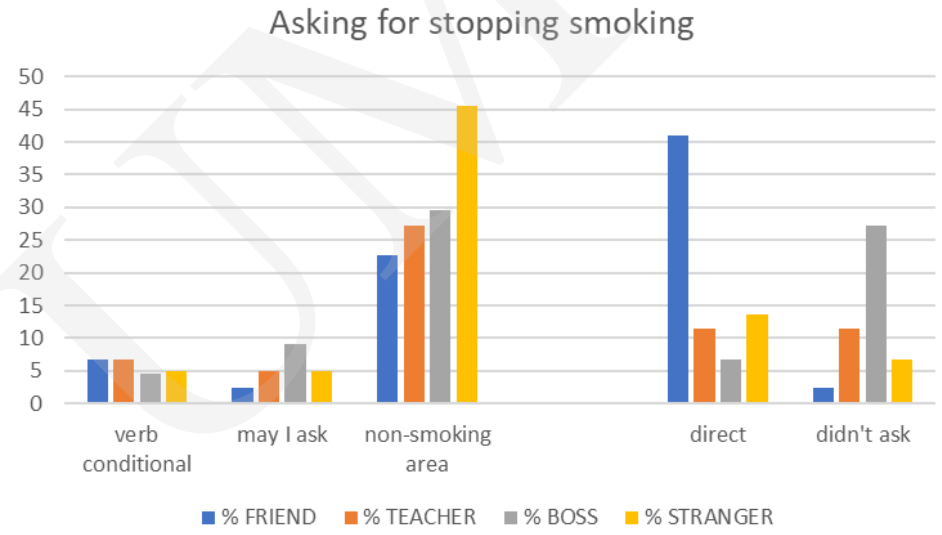

Figure 13. Asking for stopping smoking - the most popular strategies (\%) (Hungarian)

Both requests can be regarded as FTA requests, as they show our displeasure with the behavior of the addressee. In this case, direct requests appeared in interactions with friends (music: 39\%, smoking: 41\%). When asking a teacher or a stranger to stop smoking, the number of direct requests was over $10 \%$, but here it has to be added that the utterer was authorized to ask for it, as it was a non-smoking area. These types of directives were perceived as uneasy and it is shown also that several informants decided to stay silent, especially when hierarchical relations came into consideration (boss, teacher).

The second strategy that appeared was tud ('can') in a conditional mood and often in the first person plural (Why couldn't we...). It was characteristic of the situations where both the speaker and the addressee were in the same closed space, but the action itself should be executed by one person only (preferably the owner of the car).

When addressing their boss, a case of increased social distance, informants once more resorted to the megkérhetem, hogy expression ('May I ask') (11.4\%). This strat- 
Pobrane z czasopisma New Horizons in English Studies http://newhorizons.umcs.pl Data: 26/04/2023 13:03:01

egy appears when the social distance grows and complying with the request is considered difficult.

In the second situation (asking someone to stop smoking), the speaker had to make a remark expressing that the other person is violating the rules. The most popular strategy was to state that the compartment was a non-smoking compartment, i.e. they pointed at the very first element of the speech act scenario. As the social distance grew this strategy was more frequent (friend $-22.7 \%$, teacher (T) $27.3 \%$, boss $-29.6 \%$, stranger $45.5 \%$ ). The megkérhetem, hogy ('May I ask') expression also appeared in requests directed at a boss $(9 \%)$.

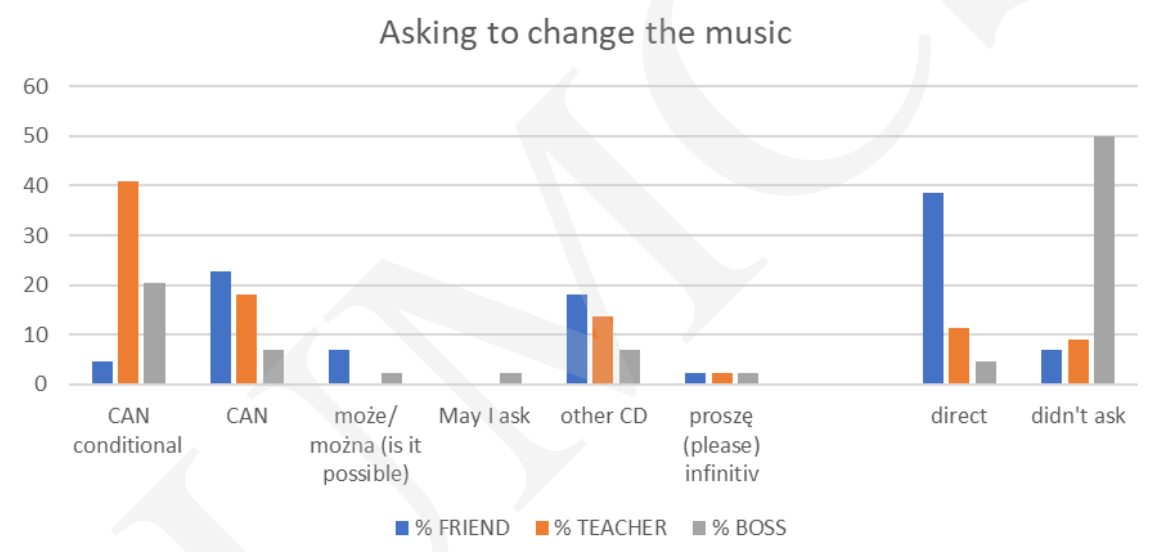

Figure 14. Asking to change the music - the most popular strategies (\%) (Polish)

\section{Asking for stopping smoking}

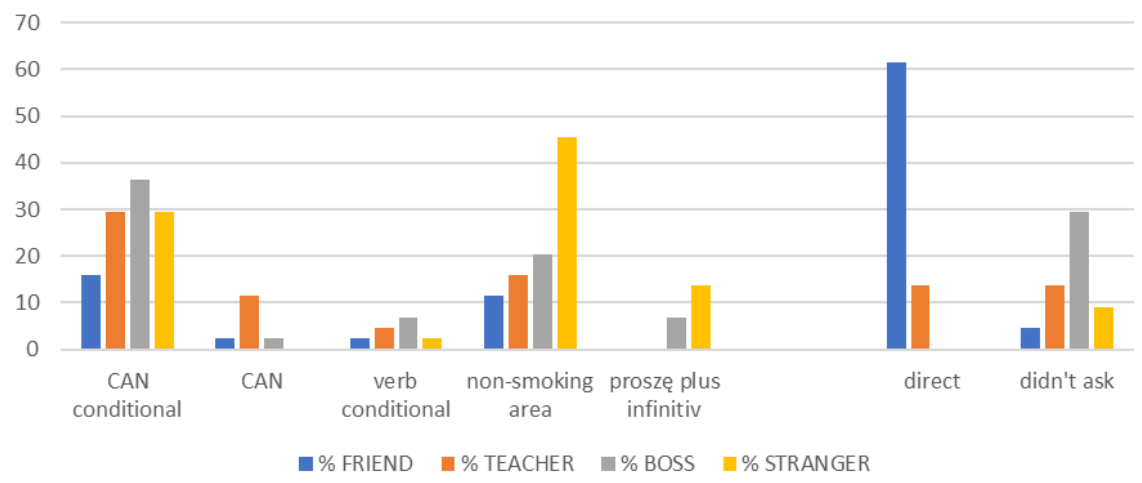

Figure 15. Asking for stopping smoking - the most popular strategies (\%) (Polish)

In answers given by Polish data providers, in these two directives, directness was common in the case of close relations (asking a friend to change the music: $38.6 \%$, asking a friend to stop smoking: $61.4 \%$ ). 
It is worth taking into consideration that impersonal forms of directives also appear (prosze plus infinitive) when asking someone to stop smoking, but only in the case of typically big social distance (boss: $6.81 \%$, stranger: $13.63 \%$ ). It has to be added that prosze (please) plus infinitive can be seen as a strong request (instruction).

In requests directed at a teacher, indirectness appeared (11.4\% - music, $13.63 \%$ - stopping smoking), but in both cases, the informants had to assume fairly close relations if they were to travel together.

The second most popular strategy was to ask using a verb meaning 'can' in a conditional form (music: teacher: $40.9 \%$, boss: $20.4 \%$, friend: $4.5 \%$, smoking: boss: $36.36 \%$, stranger: $29.5 \%$, teacher: $29.5 \%$, friend: $15 \%$ ) which shows that the expression of uncertainty was the biggest in the case of larger social distance, and in the case of can in declarative form the opposite tendency can be observed (music: teacher: $18.2 \%$, boss: $6.81 \%$, friend: $22.7 \%$, smoking: boss: $2.3 \%$, stranger: $0.0 \%$, teacher: $11.4 \%$, friend: $2.3 \%$ ).

The last strategy was to make a request by pointing out the violation of rules (saying that it is a non-smoking compartment) or asking about conditions that have to be met in order for the action to be performed (asking if the addressee has some other music), activating a very early part of the speech act scenario. This strategy became more frequent as typical social distance grew (friend: $11.36 \%$, teacher: $15.9 \%$, boss: $20.45 \%$, stranger: $45.5 \%)$.

Giving an indirect hint at changing the music was the most popular strategy in requests directed at a friend: $18.8 \%$, and then the percentage decreased (in the case of a teacher: $13.6 \%$, and a boss: $6.81 \%$ ).

When speakers exploit the very first step of the illocutionary scenario (expression of displeasure, pointing out the violation of rules, asking about the possibility of meeting necessary conditions), indirect directives can be perceived as strong instructions (in the case of large social distance, and when the violation of rules is pointed out).

In interactions of higher intimacy (friends, family members), they can be treated as hints that are used in close family relations, or relations with a large amount of shared background knowledge, and the common understanding is reached by accessing this background knowledge.

\subsubsection{Asking for a favor}

In the next two situations, participants had to ask someone to check a few pages of translation, which required the investment of time and effort (from a friend, a teacher addressed with $\mathrm{T}$ address forms, and a teacher addressed with $\mathrm{V}$ forms), and to ask for a letter that has fallen on the neighbor's balcony (here the variants concerned the age of the neighbor - young, elderly and middle-aged). 
Pobrane z czasopisma New Horizons in English Studies http://newhorizons.umcs.pl Data: 26/04/2023 13:03:01

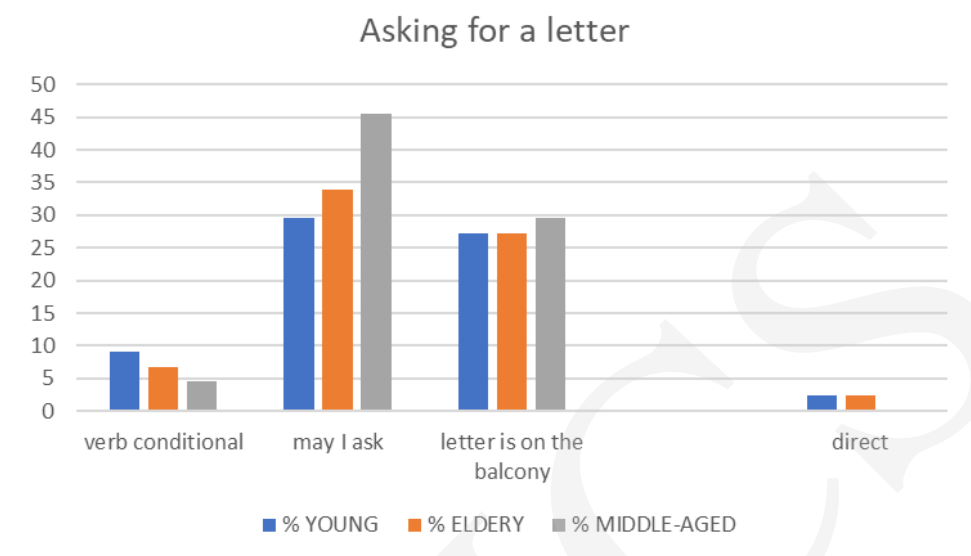

Figure 16. Asking for a letter - the most popular strategies (\%) (Hungarian)

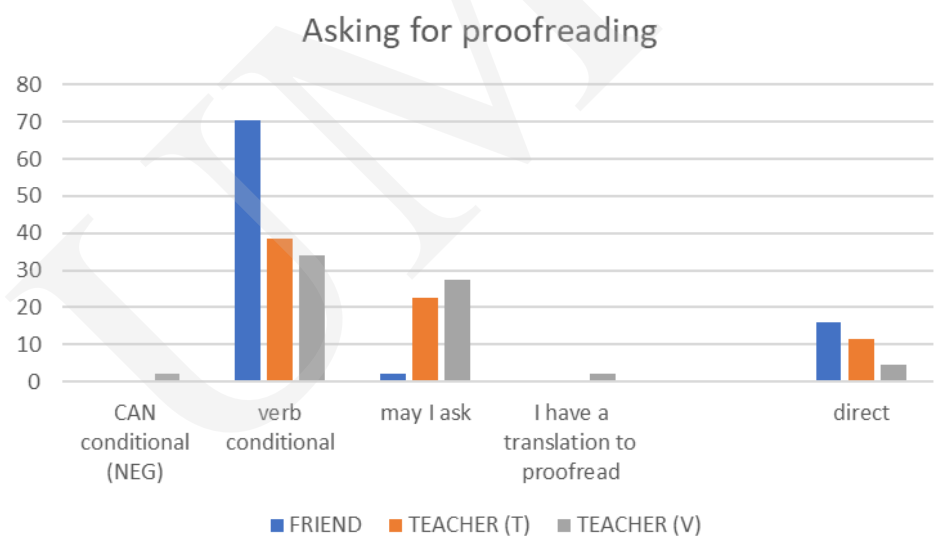

Figure 17. Asking for proofreading - the most popular strategies (\%) (Hungarian)

In the first situation, one of the most popular strategies was to say that the letter has fallen down, and its frequency grew as the social distance was growing. The second most popular strategy was to ask by using the megkérhetem, hogy ('May I ask that...') expression and its frequency grew with the age difference (and in fact, it surpassed the frequency of stating that the letter had fallen down when the neighbor was older than the informant). A similar tendency can be seen in the case of asking someone to proofread a translation (2nd person singular verb in conditional: friend: $70.5 \%$, teacher ( $\mathrm{T}$ address forms): $38.6 \%$, teacher (V address forms): 34\%). The megkérhetlek ('May I ask you...') form had a ratio of $2.3 \%$ in requests directed at a friend, $22.3 \%$ in utterances targeted at a teacher ( $\mathrm{T}$ address forms), and $27.3 \%$ when the addressee was a teacher with whom the speaker uses $\mathrm{V}$ address forms.

The frequency of direct requests deceased as the social distance grew: friend $15,9 \%$, teacher ( $\mathrm{T}$ address forms): $11,4 \%$, teacher ( $\mathrm{V}$ address forms): $4.5 \%$ ). 
Pobrane z czasopisma New Horizons in English Studies http://newhorizons.umcs.pl Data: 26/04/2023 13:03:01

Social Contexts of Indirect Requests in Polish and Hungarian

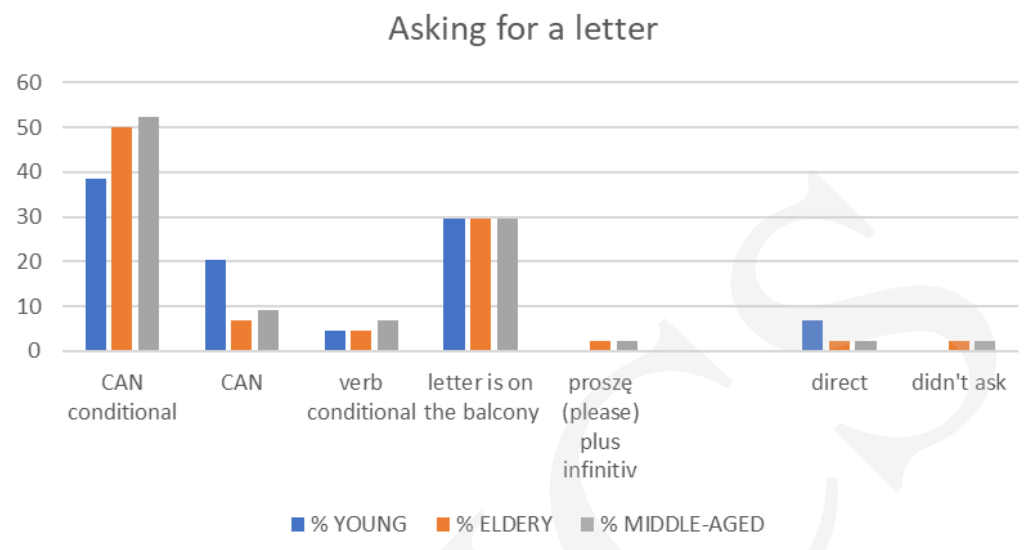

Figure 18. Asking for a letter - the most popular strategies (\%) (Polish)

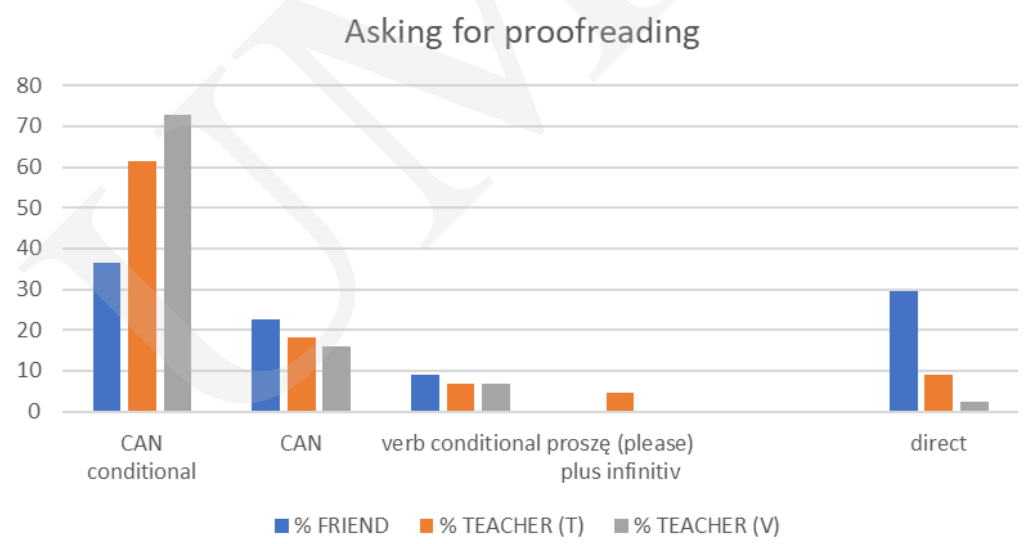

Figure no. 19 Asking for proofreading - the most popular strategies (\%) (Polish)

When asking the neighbor to give back the letter, direct requests did not appear in large numbers. They did appear, however, when speakers were asking a friend to check a translation (29.5\%), and in some cases when asking a teacher (9\%). In some cases, the expression prosze (please) plus infinitive appeared, but not in significant numbers.

The second strategy was to use a verb meaning 'can' in conditional mood in the case of the age gap between the participants. It was used more frequently as the age difference grew, or when the social distance grew. Whereas can in declarative was used most frequently among friends, and its frequency decreased as the social distance (connected with cultural schemas regarding age or power) increased.

In the case of the letter, informing the neighbor that the letter is on their balcony is also one of the strategies, but it was used in the same proportions regardless of age differences. 


\section{Summary}

In the collected material, both in Polish and in Hungarian, a majority of indirect directives were observed, and the indirectness included in them is of the BEFORE type. Direct directives appear when the relations between participants could be interpreted as close ones, based on the shared background knowledge about each other, or between participants classified as close family members. With the increase of social distance, the number of direct directives decreased. In the case of larger social distance, a type of directives that can be considered as strong instruction, impersonal imperative forms, appeared in Polish.

There was no example for the AFTER type indirectness in the answers either in Polish or in Hungarian. All of the indirect directives were exploiting the BEFORE scenarios.

In the data, further tendencies can be observed as well:

When complying with the request is considered difficult, especially in the case of larger social distance, informants used shifting the attention to the first person singular, which was especially characteristic of Hungarian respondents.

In some contexts, using the first person plural was also seen as a solution for making a request that potentially could be considered as violating one's taste (asking to change the music). In such cases, using the first person plural pronoun 'we' expressed solidarity, but clearly it was employed in the virtual use when the addressee is the participant who is expected to take an action.

Polish and Hungarian equivalents of the can auxiliary were used in conditional and indicative forms.

In the case of smaller requests, or smaller social distance, the declarative forms were used more frequently, expressing smaller uncertainty as to whether the request will be fulfilled. The conditional forms, especially in Polish, were more frequent as the weight of the request, or social distance grew. This could be observed especially in Polish answers, as 'tud' ('can') in conditional sentences is more conventional in Hungarian than its Polish equivalent (mógłbyś/mogłabyś). Polish data providers preferred to use 'can' in a form expression lower extent of uncertainty (możesz). The other common strategy was to activate the very first element of the speech-act scenario, but with two different outcomes. Exploiting the very first step of the illocutionary scenario (an expression of displeasure, pointing out the violation of rules, asking about the possibility of meeting the conditions) shows that this type of indirect directives can be perceived as strong instructions (in the case of large social distance, and when the speaker is pointing out the addressee's violation of a rule). In interactions with friends and family members, they indicate higher intimacy and the existence of a substantial amount of shared background knowledge.

In the end, it is worth mentioning that the more conventional the request, the smaller the variety of answers. In conventional situations the tendencies are stronger, since it is in conventional situations that we tend to make conventional linguistic choices, 
Pobrane z czasopisma New Horizons in English Studies http://newhorizons.umcs.pl

Data: 26/04/2023 13:03:01

Social Contexts of Indirect Requests in Polish and Hungarian

as we pay less attention to them, perceiving an extra-linguistic effort as not needed. Consequently, non-conventional language choices in very conventional situations are seen as conveying extra pragmatic meaning.

\section{Tables}

Table 1. Number and education level of participants

\begin{tabular}{|c|c|c|c|c|}
\hline L1 & \multicolumn{4}{|c|}{ POLISH } \\
\hline GENDER & \multicolumn{2}{|c|}{ WOMEN } & \multicolumn{2}{|c|}{ MEN } \\
\hline EDUCATION LEVEL & SECONDARY & HIGHER & SECONDARY & HIGHER \\
\hline $\begin{array}{l}\text { NUMBER OF } \\
\text { PARTICIPANTS }\end{array}$ & 23 & 3 & 11 & 7 \\
\hline PERCENTAGE & 52.3 & 6.8 & 25 & 15.9 \\
\hline L1 & HUNGARIAN & & & \\
\hline GENDER & \multicolumn{2}{|c|}{ WOMEN } & \multicolumn{2}{|c|}{ MEN } \\
\hline EDUCATION LEVEL & SECONDARY & HIGHER & SECONDARY & HIGHER \\
\hline $\begin{array}{l}\text { NUMBER OF } \\
\text { PARTICIPANTS }\end{array}$ & 30 & 2 & 9 & 2 \\
\hline PERCENTAGE & 69.8 & 4.65 & 20.9 & 4.65 \\
\hline
\end{tabular}

Table no. 3 Asking for a ticket (\%)

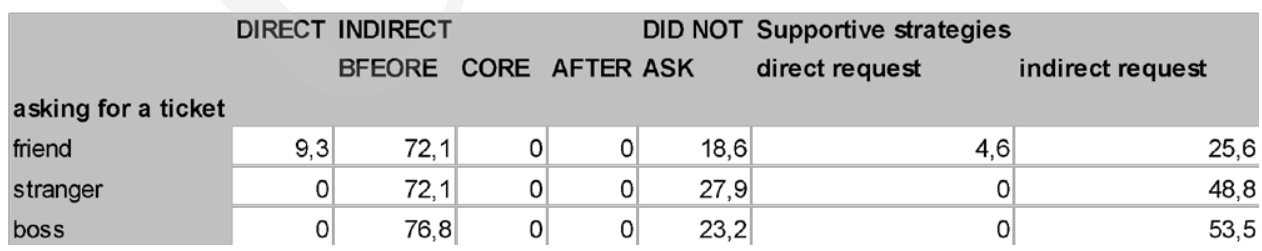

Table no. 4 Asking the addressee to stop smoking (\%)

\begin{tabular}{|c|c|c|c|c|c|c|c|c|c|c|}
\hline & & DIRECT & $\Gamma$ INDIRECT & & & ID NOT & T Suppo & ortive stra & ategies & \\
\hline & & & BFEORE & CORE & AFTER A & SK & direct & & indire & \\
\hline a sking stopping s & smokig & & & & & & & & & \\
\hline $\mathrm{T}$ addressive forms & & 16,2 & 67,4 & 0 & 4,7 & 11, & & & 2,3 & 48,8 \\
\hline$V$ addressive forms & & 20,9 & 51,2 & 0 & 2,3 & 25 & & & 11,7 & 27,9 \\
\hline$\%$ & ITEM, VA & ALUE & & & & & & & & $\mathrm{HU}$ \\
\hline & LOAN & & & BUS TIC & KET & & KEY & & & \\
\hline & FRIEND & TEACHER A & AQUAINTANCE & FRIEND & STRANGER & BOSS & MOTHER & SIBILING & GRANDMOTHER & MOTHER-IN-LAW \\
\hline CAN_conditional & 45,5 & 11,4 & 41 & 29,6 & 27,3 & 27,3 & 27,3 & 22,8 & 27,3 & 34 \\
\hline CAN_neg. Conditional & 27,3 & 11,4 & 18,2 & 4,5 & 6,8 & 6,8 & 0 & 0 & 0 & 0 \\
\hline having a ticket (neg) & 0 & 0 & 0 & 43,2 & 27,3 & 36,4 & 0 & 0 & 0 & 0 \\
\hline Maylask & 0 & 6,8 & 9 & 4,5 & 4,5 & 0 & 4,5 & 11,4 & 20,5 & 27,3 \\
\hline direct & 4,5 & 0 & 4,5 & 9 & 0 & 0 & 43,2 & 34 & 25 & 6,8 \\
\hline didn't ask & 9 & 43,2 & 20,5 & 4,5 & 27,3 & 22,8 & 4,5 & 0 & 4,5 & 11,4 \\
\hline
\end{tabular}

Table no. 5 Asking for an item, value - the most popular strategies (\%) (Hungarian) 
Pobrane z czasopisma New Horizons in English Studies http://newhorizons.umcs.pl

Data: 26/04/2023 13:03:01

Agnieszka Veres-Guśpiel

Table 6. Asking for an item, value - the most popular strategies (\%) (Polish)

\begin{tabular}{|c|c|c|c|c|c|c|c|c|c|c|}
\hline$\%$ & ITEM, VA & ALUE & & & & & & & & PL \\
\hline & LOAN & & & BUS TIC & KET & & KEY & & & \\
\hline & FRIEND & TEACHER & AQUANTANCE & FRIEND & STRANGER & BOSS & MOTHER & SIBILING & GRANDMOTHER & MOTHER-IN-LAW \\
\hline CAN_conditional & 40,9 & 22,7 & 36,4 & 4,5 & 18,18 & 20,45 & 6,81 & 9 & 15,9 & 40,9 \\
\hline CAN & 18,2 & 2,3 & 11,36 & 9 & 2,3 & & 15,9 & 22,7 & 22,7 & 18,2 \\
\hline verb_conditional & 2,3 & 2,3 & 6,81 & 6,81 & 2,3 & 4,5 & 4,5 & 4,5 & 4,5 & 2,3 \\
\hline having a ticket (neg) & 2,3 & 2,3 & 2,3 & 11,4 & 6,81 & 11,4 & & & & \\
\hline having a ticket (aff.) & 2,3 & 2,3 & 2,3 & 38,6 & 35 & 20,45 & 6,81 & 4,5 & 4,5 & 2,3 \\
\hline & & & & & & & & & & \\
\hline direct & 20,4 & 2,3 & 6,8 & 22,7 & & 2,3 & 61,4 & 47,7 & 40,9 & 6,8 \\
\hline didn't ask & 6,8 & 52,3 & 29,6 & 4,5 & 40,9 & 34 & 2,3 & 2,3 & 2,3 & 22,7 \\
\hline
\end{tabular}

Table no. 7 Asking for a favor combined with FTA remark - most popular strategies (\%) (Hungarian)

\begin{tabular}{|l|l|l|l|r|r|r|r|r|}
\hline$\%$ & DIRECTIVE - FTA REMARK & & & & \multicolumn{2}{l|}{ HU } \\
\hline & & MUSIC & & & SMOKING & & & \\
\hline & & FRIEND & TEACHER & BOSS & FRIEND & TEACHER & BOSS & STRANGER \\
\hline CAN_conditional (NEG) & & 0 & 0 & 0 & 0 & 0 & 0 & 0 \\
\hline verb_conditional & & $\mathbf{2 7 , 3}$ & $\mathbf{3 6 , 4}$ & 4,5 & 6,8 & 6,8 & $\mathbf{4 , 5}$ & $\mathbf{5}$ \\
\hline May I ask & & 0 & 6,8 & $\mathbf{1 1 , 4}$ & 2,3 & 5 & 9 & $\mathbf{2 2}$ \\
\hline non-smoking area & & 4,5 & 4,5 & 2,3 & $\mathbf{2 2 , 7}$ & $\mathbf{2 7 , 3}$ & $\mathbf{2 9 , 6}$ & $\mathbf{4 5 , 5}$ \\
\hline & & & & & & & & $\mathbf{1 3 , 6}$ \\
\hline direct & & $\mathbf{3 8 , 6}$ & 6,8 & 6,8 & $\mathbf{4 1}$ & $\mathbf{1 1 , 4}$ & 6,8 & $\mathbf{1 3 , 6}$ \\
\hline didn't ask & & 0 & 9 & $\mathbf{5 2 , 3}$ & 2,3 & $\mathbf{1 1 , 4}$ & $\mathbf{2 7 , 3}$ & $\mathbf{6 , 8}$ \\
\hline
\end{tabular}

Table no. 8 Asking for a favor combined with FTA remark

- most popular strategies (\%) (Polish)

\begin{tabular}{|c|c|c|c|c|c|c|c|}
\hline$\%$ & DIRECTIVE - FTA F & REMARK & & & & & PL \\
\hline & MUSIC & & & SMOKING & & & \\
\hline & FRIEND & TEACHER & BOSS & FRIEND & TEACHER & BOSS & STRANGER \\
\hline CAN_conditional & 4,5 & 40,9 & 20,4 & 15,9 & 29,5 & 36,36 & 29,5 \\
\hline CAN & 22,7 & 18,2 & 6,81 & 2,3 & 11,4 & 2,3 & \\
\hline może/ można (is it possible) & 6,81 & & 2,3 & & & & \\
\hline May I ask & & & 2,3 & & & & \\
\hline verb_conditional & & & & 2,3 & 4,5 & 6,81 & 2,3 \\
\hline non-smoking area & & & & 11,36 & 15,9 & 20,45 & 45,5 \\
\hline other CD & 18,18 & 13,6 & 6,81 & & & & \\
\hline proszę plus infinitive & 2,3 & 2,3 & 2,3 & & & 6,81 & 13,63 \\
\hline direct & 38,6 & 114 & 45 & 614 & 1363 & & \\
\hline didn't ask & 6,81 & 9 & 50 & 4,5 & 13,63 & 29,5 & 9,09 \\
\hline
\end{tabular}

Table no. 9 Asking for a favor - most popular strategies (\%) (Hungarian)

\begin{tabular}{l|r|r|r|r|r|r|r}
\hline & \multicolumn{2}{|l|}{ FAVOUR } & & & & & HU \\
\hline & & LETTER & & & \multicolumn{2}{|l|}{ TRANSLATION } & \\
\hline & & YOUNG & ELDERY & MIDDLE-AGED & FRIEND & TEACHER (T) & TEACHER (V) \\
\hline CAN_conditional (NEG) & & 0 & 0 & 0 & 0 & 0 & 2,3 \\
\hline verb_conditional & & 9 & 6,8 & 4,5 & $\mathbf{7 0 , 5}$ & $\mathbf{3 8 , 6}$ & $\mathbf{3 4}$ \\
\hline May I ask & & $\mathbf{2 9 , 6}$ & $\mathbf{3 4}$ & $\mathbf{4 5 , 5}$ & 2,3 & $\mathbf{2 2 , 7}$ & $\mathbf{2 7 , 3}$ \\
\hline letter is on the balcony & & $\mathbf{2 7 , 3}$ & $\mathbf{2 7 , 3}$ & $\mathbf{2 9 , 6}$ & 0 & 0 & 2,3 \\
\hline & & & & & & & \\
\hline direct & & 2,3 & 2,3 & 0 & $\mathbf{1 5 , 9}$ & 11,4 & 4,5 \\
\hline didn'task & & 0 & 0 & 0 & 0 & 0 & 0 \\
\hline
\end{tabular}


Pobrane z czasopisma New Horizons in English Studies http://newhorizons.umcs.pl Data: 26/04/2023 13:03:01

Social Contexts of Indirect Requests in Polish and Hungarian

Table no. 10 Asking for a favor - most popular strategies (\%) (Polish)

\begin{tabular}{|c|c|c|c|c|c|c|}
\hline$\%$ & FAVOUR & & & & & $\mathrm{PL}$ \\
\hline & LETTER & & & TRANSLA & ATION & \\
\hline & YOUNG & ELDERY & MIDDLE-AGED & FRIEND & TEACHER (T) & TEACHER (V) \\
\hline CAN_conditional & 38,63 & 50 & 52,3 & 36,36 & 61,4 & 72,7 \\
\hline CAN & 20,45 & 6,81 & 9,09 & 22,7 & 18,18 & 15,9 \\
\hline verb_conditional & 4,5 & 4,5 & 6,81 & 9,09 & 6,81 & 6,81 \\
\hline letter is on the balcony & 29,5 & 29,5 & 29,5 & & & \\
\hline prosze plus infinitive & & 2,3 & 2,3 & & 4,5 & \\
\hline & & & & & & \\
\hline direct & 6,81 & 2,3 & 2,3 & 29,5 & 9 & 2,3 \\
\hline didn't ask & & 2,3 & 2,3 & & & \\
\hline
\end{tabular}

\section{References}

Barcelona, Antonio. 2000. Metaphor and Metonymy at the Crossroads. Berlin: Mouton de Gruyter.

Blum-Kulka, Shoshana and Olshtain, Elite. 1984. "Request and Apologies." Applied Linguisitics 3: 196-213

Brdar, Mario, and Rita Brdar-Szabó. 2017 “How Metonymy and Grammar Interact” In Studies in Figurative Thought and Language, ed. Angeliki Athanasiadou, 126-149. Amsterdam: John Benjamins.

Brown, Penelope, and Stephen Levinson. 1987. Politeness. Some Universals in Language Use. Cambridge: Cambridge University Press.

Croft, William. 1993. "The Role of Domains in the Interpretation of Metaphors and Metonymies." Cognitive Linguistics 4: 335-370.

Croft, William. 2009. "Towards a Social Cognitive Linguistics.” In New Directions in Cognitive Linguistics, ed. Evans Vyvyan and Poursel Stephanie, 395-420. Amsterdam: John Benjamins.

Csató, Valéria, and Csaba Pléh. 1988. "Indirekt felszólítások a magyar nyelvben. (Indirect Directives in Hungarian.)" Magyar Pszichológiai Szemle: 99-115.

Fillmore, Charles J. (1982) 2006. "Frame Semantics." In Cognitive Linguistics: Basic Readings, ed. Geeraerts Dirk, 373-400. Berlin, New York: Mouton de Gruyter.

Gazzaniga, Michael. (2008) 2011. Istota człowieczeństwa. (Human. The science Behind what makes us unique). Sopot: Smak słowa.

Kövecses, Zoltán, and Grünter Radden. 1998. "Metonymy: Developing a Cognitive Linguistic View." Cognitive Linguistics 9 (1): 37-77.

Kövecses, Zoltán. 2005. A metafora. Gyakorlati bevezetés a kognitiv metaforaelméletbe. (Metaphor. A Practical Introduction to the Cognitive Theory of Metaphors). Budapest: Typotex.

Lakoff, George. 1987. Women, Fire and Dangerous Things: What Categories Reveal about the Mind. Chicago: The University of Chicago Press.

Langacker, Ronald W. 1993. "Reference-point Constructions." Cognitive Linguistics 4:1-38. 
Panther, Klaus-Uwe. 2011. "Motivation in Language." In Cognition and Motivation: Forging an Interdisciplinary Perspective, ed. Kreitler Shulamith. Cambridge: Cambridge University Press. http://www.lexicom.es/drupal/files/Panther.Motivation\%202011.pdf

Panther, Klaus-Uwe and Linda Thornburg. 1998. "A Cognitive Approach to Interferencing in Conversation." Journal of Pragmatics 30: 755-769.

Panther, Klaus-Uwe, and Linda Thornburg. 1999. "The Potentiality for Actuality Metonymy in English and Hungarian." In Metonymy in Language and Thought (Human Cognitive Processing 4), ed. Panther, Klaus-Uwe and Günter Radden, 333-357. Amsterdam and Philadelphia: Benjamins.

Panther, Klaus-Uwe, and Linda Thornburg. 2003. "Metonymies as Natural Inference and

Activation Schemas: The Case of Dependent Clauses as Independent Speech Acts. "In Metonymy and Pragmatic Inferencing, ed. Panther, Klaus-Uwe and Linda Thornburg, 127-147. Amsterdam and Philadelphia: Benjamins.

Panther, Klaus-Uwe and Linda Thornburg. 2006. "Metonymy and the Way we Speak." In The Metaphors of Sixty: Papers Presented on the Occasion of the 60th Birthday of Zoltán Kövecses, ed. Benczes Réka and Szilvia Csábi, 183-195. Budapest: Eötvös Loránd University Press.

Panther, Klaus-Uwe, and Linda Thornburg. 2007. "Metonymy." In The Oxford Handbook of Cognitive Linguistics ed. Geeraerts Dirk and Hubert Cuyckens, 236-264. New York: Oxford University Press.

Panther, Klaus-Uwe, Linda Thornburg, and Antonio Barcelona. 2009. Metonymy and Metaphor in Grammar. Human Cognitive Processing, 25. Amsterdam and Philadelphia: Benjamins

Panther, Klaus-Uwe, and Linda Thornburg. 2017. "Metaphor and Metonymy in Language and Thought: A Cognitive Linguistic Approach." SYNTHESIS PHILOSOPHICA 64 (2): 271294

Panther, Klaus-Uwe, and Günter Radden. 1999. "The Potentiality for Actuality Metonymy in English and Hungarian." In Metonymy in Language and Thought. eds. Panther Klaus-Uwe and Günter Radden, 333-357. Amsterdam and Philadelphia: Benjamins.

Pléh, Csaba. 2012. A társalgás pszichológiája. (The psychology of conversation.). Budapest: Libri Könyvkiadó.

Tátrai, Szilárd. 2013. "Funkcionális pragmatika és kognitív nyelvészet. (Functional pragmatics and cognitive linguistics.)" Magyar Nyelv 109 (2):197-202.

Radden, Günter, and Klaus-Uwe Panther. 2004. "Introduction: Reflections on Motivation.” In Studies in Linguistic Motivation (Cognitive Linguistics Research 28), ed. Radden Günter and Klaus-Uwe Panther, 1-46. Berlin and New York: Mouton de Gruyter.

Tátrai, Szilárd. 2017. "Pragmatika. (Pragmatics.)" In Nyelvtan ed. Tolcsvai Nagy Gábor, 8991057. Budapest: Osiris Kiadó.

Thornburg, Linda and Klaus-Uwe Panther. 1997. "Speech Act Metonymies." In Discourse and Perspective in Cognitive Linguistics. ed. Liebert Wolf-Andreas, Redeker Gisela, and Linda R.Waugh, 205-219. Amsterdam: John Benjamins.

Tomasello, Michael. 2016. Dlaczego wspótpracujemy. (Why we cooperate). Copernicus Center Press. 
Pobrane z czasopisma New Horizons in English Studies http://newhorizons.umcs.pl Data: 26/04/2023 13:03:01

Wardhaugh, Roland 2005 (1995). Szociolingvisztika (eredeti cime: An Introducion to Sociolinguistics). Osiris Kiadó, Budapest.

Watts, Richard. 2003. Politeness. Cambridge: Cambridge University Press.

Watts, Richard and Miriam Locher. 2005. "Politeness Theory and Relational Work." Journal of Politeness Research. 1 (1): 9-33

Verschueren, Jef. 1999. Understanding Pragmatics. London, New York, Sydney, Auckland: Arnold.

Veres-Guśpiel, Agnieszka 2013. “Kérések konstruálása - kidolgozottság, indirektség, konvencionáltság hatása a megnyilatkozások udvariasságára” In Társadalmi változások - nyelvi változások. Alkalmazott nyelvészeti kutatások a Kárpát-medencében. A XXII. MANYE Kongresszus elöadásai. Szeged, 2012. április 12-14. (A MANYE Kongresszusok előadásai 9.), ed: Tóth Sziergiej, 289-296 Budapest-Szeged: MANYE - Szegedi Egyetemi Kiadó Juhász Gyula Felsőoktatási Kiadó. http://mek.oszk.hu/11700/11730/11730.pdf

Veres-Guśpiel, Agnieszka 2017. A személyközi viszonyok konstruálásának kognitív pragmatikai vizsgálata a magyar és a lengyel nyelvü kérésekben. (Cognitive pragmatic research on constructing interpersonal relationships in Hungarian and Polish requests. Doctoral dissertation, Budapest. https://edit.elte.hu/xmlui/bitstream/handle/10831/33370/dissz_veres-guspiel_agnieszka_nyelvtud.pdf;jsessionid=C03BE8DE680ECE2C3BB1FB558ABF9EFA?sequence $=1$ 